\title{
TRACING THE ARGUELLO SUBMARINE CANYON SYSTEM FROM SHELF ORIGINS TO AN ABYSSAL SINK
}

\author{
K.M. MARSAGLIA, B. RODRIGUEZ, D.S. WEERARATNE \\ Department of Geological Sciences, California State University Northridge, 18111 Nordhoff Street, Northridge, \\ California 91330, USA \\ e-mail: kathie.marsaglia@csun.edu
}

H.G. GREENE

Moss Landing Marine Laboratories, 7700 Moss Landing Road, Moss Landing, California 95039, USA

N. SHINTAKU

Department of Geological Sciences, California State University Northridge, 18111 Nordhoff Street, Northridge, California 91330, USA

AND

\section{M.D. KOHLER}

Division of Engineering and Applied Science, California Institute of Technology, Pasadena, California 91125, USA

\begin{abstract}
The Arguello submarine canyon/channel system extends over $300 \mathrm{~km}$ from the continental shelf off Point Arguello and Point Conception in southern California westward onto the oceanic crust of the Pacific plate. In the northernmost reaches where the canyon system originates, all stages in the evolution of seafloor morphologic fluid flow features - from pockmarks to gullies to converging rills - are observed, similar to what has been described for the Ascension slope, north of Monterey Bay. These features appear to be active today and are linked to fluid leakage from the underlying hydrocarbon basin. The channel dissects a continental slope that exhibits features consistent with large-scale mass wasting. Upslope scarps may be the source of the morphological feature at the base of the slope previously referred to as the "Arguello submarine fan," with topographic expressions (e.g., large channel meanders, ridges) that are more consistent with mass transport deposits than with deep-sea fan depositional lobes. The modern canyon crosscuts these deposits and parallels an older, meandering channel/canyon to the west. Modern seismicity along the shelf and slope may have, and potentially still can, trigger landslides on the slope. Seismicity associated with seamount volcanism, past subduction, and Borderland transrotational and extensional processes most likely played a role in stimulating mass wasting. The presence of abundant nearby petroleum suggests that gas venting and hydrate dissociation cannot be ruled out as a triggering mechanism for the slope destabilization occurring today. The canyon/channel continues due south on a path possibly determined by the structural grain of north-south-aligned abyssal hills underlying oceanic basement. At latitude $33^{\circ} 18^{\prime} \mathrm{N}$, the channel makes a $90^{\circ}$ turn (bend) to the west at the E-W-striking Arguello transform fault wall and develops into a meandering channel system that crosses over abyssal hill crustal fabric. The system ultimately straightens as it continues west before veering north, curving around a thickened crustal bulge at a corner offset in the Arguello fracture zone in complex basement structure, and then finally empties into an 800-m-deep basin depocenter.
\end{abstract}

KEY woRDs: submarine canyon, submarine channel, California Borderland, seep, mass transport

\section{INTRODUCTION}

The Arguello Canyon, a sparsely studied deep-sea channel and fan system, originates on the northwestern edge of the California Continental Borderland. It extends over $300 \mathrm{~km}$ from the continental shelf off Point Conception in Southern California, near the mouth of the Santa Ynez River, across the slope to the deep sea, continuing west onto Pacific oceanic crust (Figs. 1, 2). In this region, the oceanic crust exhibits a complex pattern of magnetic anomalies, which are continuous and $\mathrm{N}-\mathrm{S}$ trending on the oldest seafloor but which are discontinuous and oriented in a NNE orientation near the Patton escarpment between the Murray and Arguello fracture zones (see Fig. 1). The Arguello Fracture zone (AFZ), defined by discontinuities in the magnetic anomalies (Atwater and Severinghaus 1988), has an arcuate shape that trends westward at the Patton Escarpment and bends northward to meet the Murray Fracture Zone (MFZ). The MFZ is the major seafloor tectonic structure offshore of southern California and trends WSW but bends to the NE at $123^{\circ} \mathrm{W}$ longitude, where it forms a "Y" with the AFZ. The Arguello Canyon system is contained within this "Y" between the MFZ and the AFZ, which outlines a region of the seafloor that was captured by the Pacific plate during the shallow subduction of the Farallon Plate and the East Pacific Rise spreading center. Intersection of the spreading center at 29 to $30 \mathrm{Ma}$ contributed to the evolution of the San Andreas Fault system (e.g., Atwater and Severinghaus 1988; Fig. 1). Rotation of the Transverse Ranges began later, at 17 to $18 \mathrm{Ma}$, and is ongoing today and is reported to have rotated over $90^{\circ}$ in some locations (Luyendyk 1991). The seafloor magnetic anomalies (anomalies 5 and 6) within the "Y" of the MFZ and AFZ appear slightly rotated in a clockwise direction to the ENE. The Arguello Canyon cuts southward across the slope between the Santa Lucia Bank/escarpment and the Rodriguez 


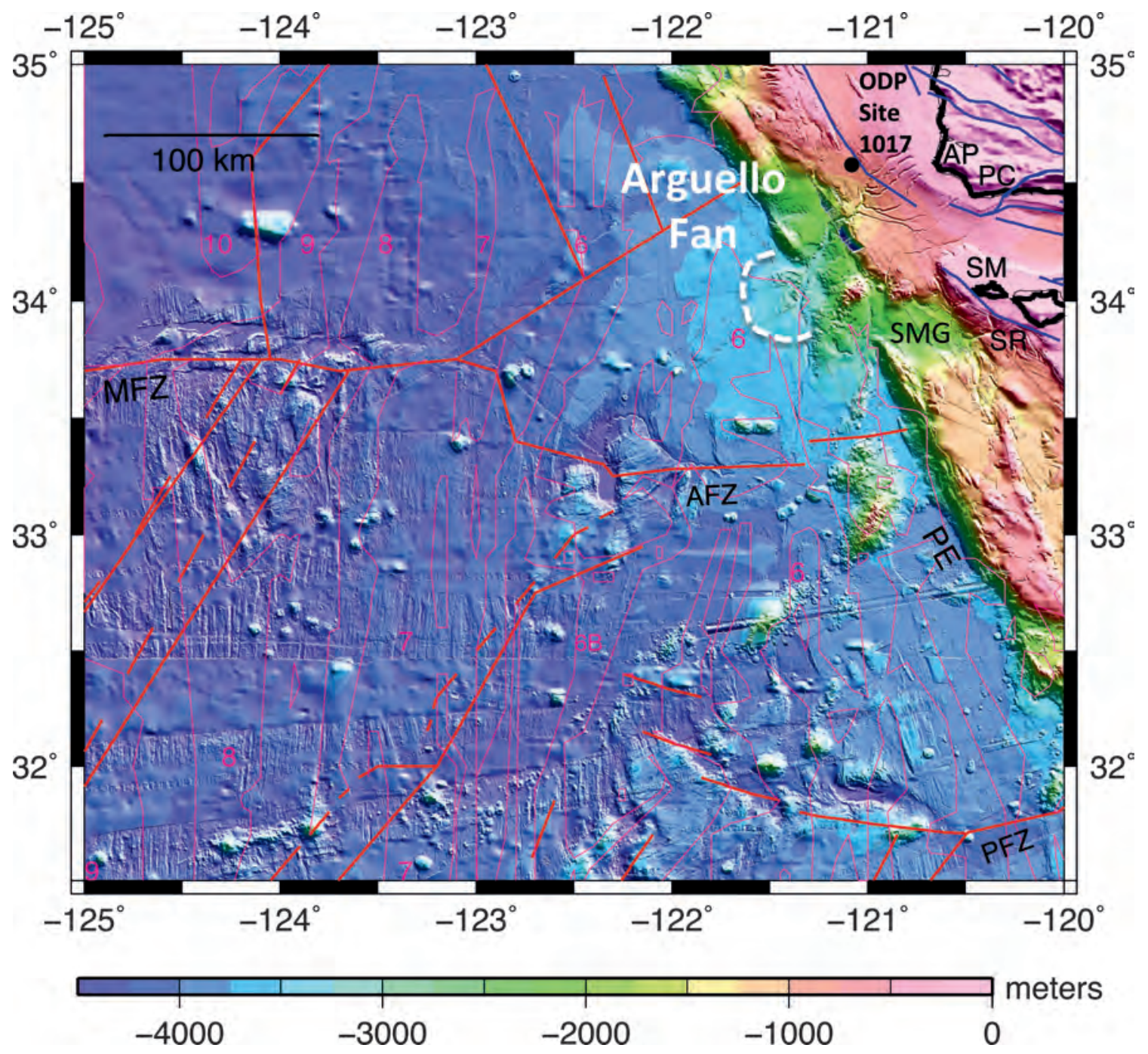

FIG. 1.- Regional bathymetric map showing compilation of new ALBACORE (Legg et al. 2015) and all previous NGDC ship track data (prior to 2010 ALBACORE cruise) and magnetic seafloor anomalies (Atwater and Severinghaus 1988). Abbreviations show the locations of Arguello Point (AP); Point Conception (PC); Arguello Fracture Zone (AFZ); Patton Escarpment (PE); Murray Fracture Zone (MFZ); San Miguel Island (SM); Santa Rosa Island (SR); San Miguel Gap (SMG); and Patton Fracture Zone (PFZ). Bold red lines are fracture zones, inferred pseudofaults, whereas thin red lines mark the magnetic anomalies. Red numbers placed in positive magnetic regions refer to ageconstrained reversals (e.g., at $5[\sim 10 \mathrm{Ma}$, $6[\sim 20 \mathrm{Ma}], 10[\sim 30 \mathrm{Ma}]$ ). Scale bar shows color scale in meters below sea level. Faults (blue lines) shown onshore and in the outer Borderland are described in a focused fault study by Legg et al. (2015). Filled black circle indicates the location of Ocean Drilling Program (ODP) Site 1017 (Lyle et al. 1997).

Seamount, due west of the Santa Barbara Channel and Channel Islands, and parallels the N-S-trending abyssal hill fabric (Fig. 2).

Compared to canyon-fed fan systems elsewhere in the Inner California Continental Borderland (e.g., Normark et al. 2009) and the Monterey Canyon system to the north (e.g., Greene et al. 2002), the Arguello Canyon system is less studied. As bathymetric data were first collected along the California continental margin, elements of the Arguello submarine canyon/channel system and associated submarine fan were incrementally described and defined, as summarized in the influential work of Shepard and Emery (1941). The Arguello Canyon system was a case study in Buffington's (1952) seminal article defining and interpreting deep-sea channel and levee systems. Later,
Menard (1955, 1960) only mentioned the Arguello Canyon and fan while concentrating on other larger canyon/fan systems (e.g., Monterey Canyon) that were defined using Precision Depth Recorder measurement profiles with an average spacing of 1 mile and precision of 1 fathom. In contrast, Von Huene (1969) focused more on the Arguello Canyon system, as it lies in a zone of tectonic interest between the MFZ and the Transverse Ranges.

Using seismic-reflection profile data, Von Huene (1969) described a series of tributary channels on the shelf that coalesced into the Arguello Canyon, which he depicted as extending down from the shelf to slope and feeding the Arguello Fan at the base of the slope. He supported Palmer's (1964) suggestion that this slope canyon was 


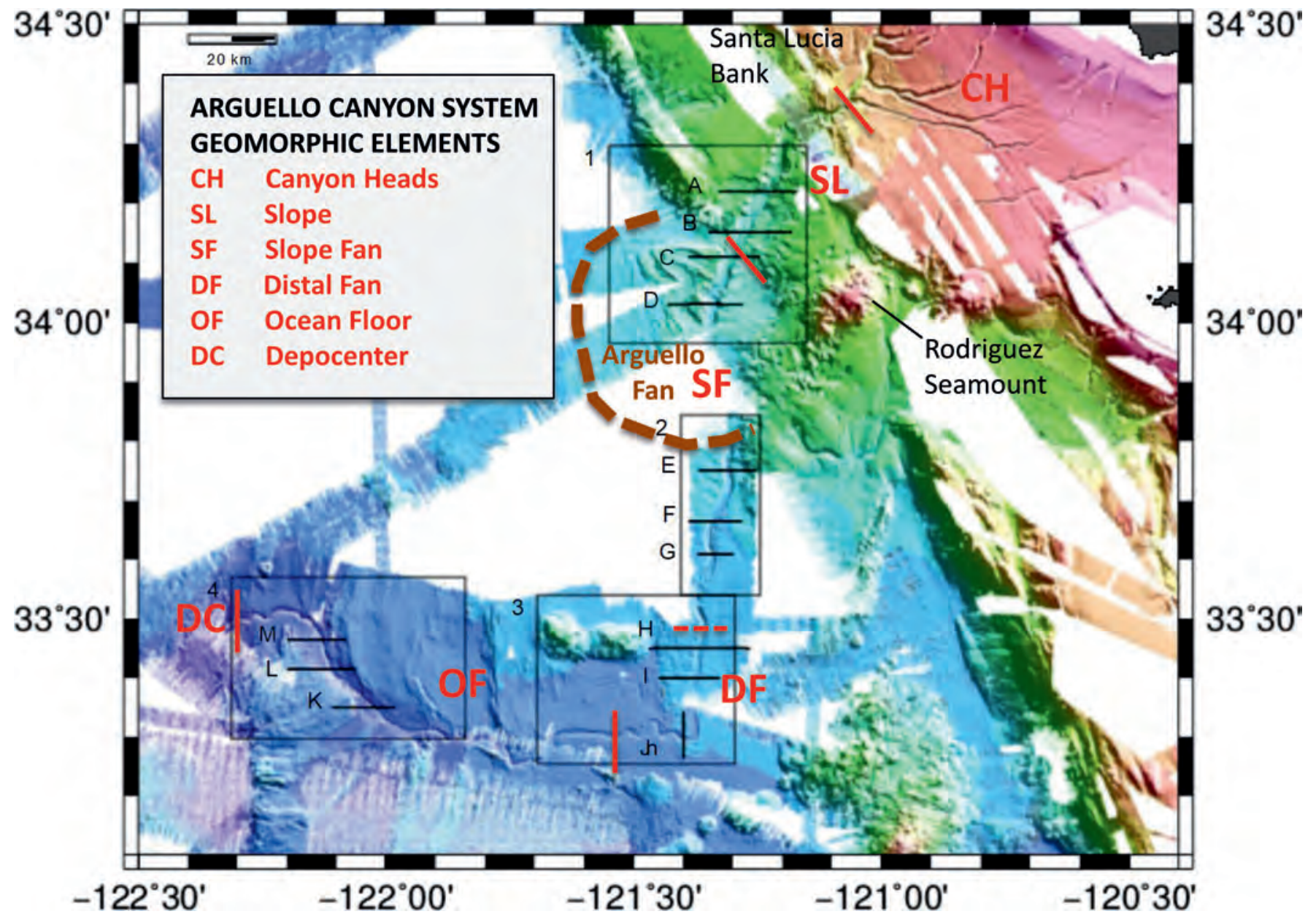

FIG. 2.-Bathymetric map focusing on the Arguello Canyon system, from shelf to ultimate sink, created from data compilation of 126 NGDC ship tracks and the ALBACORE project (Legg et al. 2015). Boxed areas 1 through 4 are enlarged in Figures 7 and 9 . Dashed brown line shows general location of fan, as depicted by early workers (e.g., von Huene 1969). Geomorphic elements of the Arguello Canyon system are delineated by red lines from the canyon head $(\mathrm{CH})$ region in the northeast, to the slope (SL), slope fan (SF), distal fan (DF), ocean floor (OF), and depocenter (DC) in the southwest. Note that the boundary between slope and distal fan segments is dashed to reflect uncertainty in the delineation of fan deposits.

structurally controlled. In a line drawing of a seismic-reflection profile across the continental slope, Von Huene (1969) interpreted the sediments at the base of the slope to be deposited in a fan-like feature, with the canyon system terminating on the fan.

Modern investigators, including Donn Gorsline, concentrated their studies on the shelf to upper slope section of the system. For example, Reynolds and Gorsline (1988) surveyed the area from Point Arguello to Point Conception, noting the presence of an unusual series of slope depressions. Later work by Slater et al. (2002) described the shelf north of Point Arguello as a ramp where the Santa Ynez River has filled shelf accommodation space. Holocene sediment thickness is locally in excess of $40 \mathrm{~m}$, as determined by high-resolution seismicreflection profiles across the shelf, in areas landward of where the shelf break occurs at $150 \mathrm{~m}$. In contrast, the shelf south of Point Arguello, extending to Point Conception, was described by Slater et al. (2002) as a starved shelf with $<10$-m-thick Holocene sediment cover and exposed rocky substrate.

The inspiration for this study comes from recently acquired highresolution bathymetric data sets that allow for more detailed mapping of the canyon/channel, tracing it westward over $300 \mathrm{~km}$ across the seafloor, where it terminates in a deep seafloor basin. Some of these ship-track bathymetry data were collected in the 2010 Asthenospheric and Lithospheric Broadband Architecture from the California Offshore Region Experiment (ALBACORE) marine seismic cruise that mapped out lengthy sections of the channel, which were previously imaged as part of a broader ocean bottom seismometer deployment (Legg et al. 2015; Fig. 2). Monterey Bay Aquarium Research Institute (MBARI) EM300 ${ }^{\mathrm{TM}}$ and $R / V$ Sikuliaq multibeam echosounder (MBES) bathymetric data collected in the northern shelf and upper slope reaches of the canyon system are used to examine the nature of the canyon heads. Additional insight into the system was provided by compilations of data in Google Earth Pro@ for the region. Herein we present images based on these data sets and our preliminary interpretations. Our hope is that this work will inspire future detailed studies of this interesting and heretofore poorly investigated submarine canyon/channel system. 


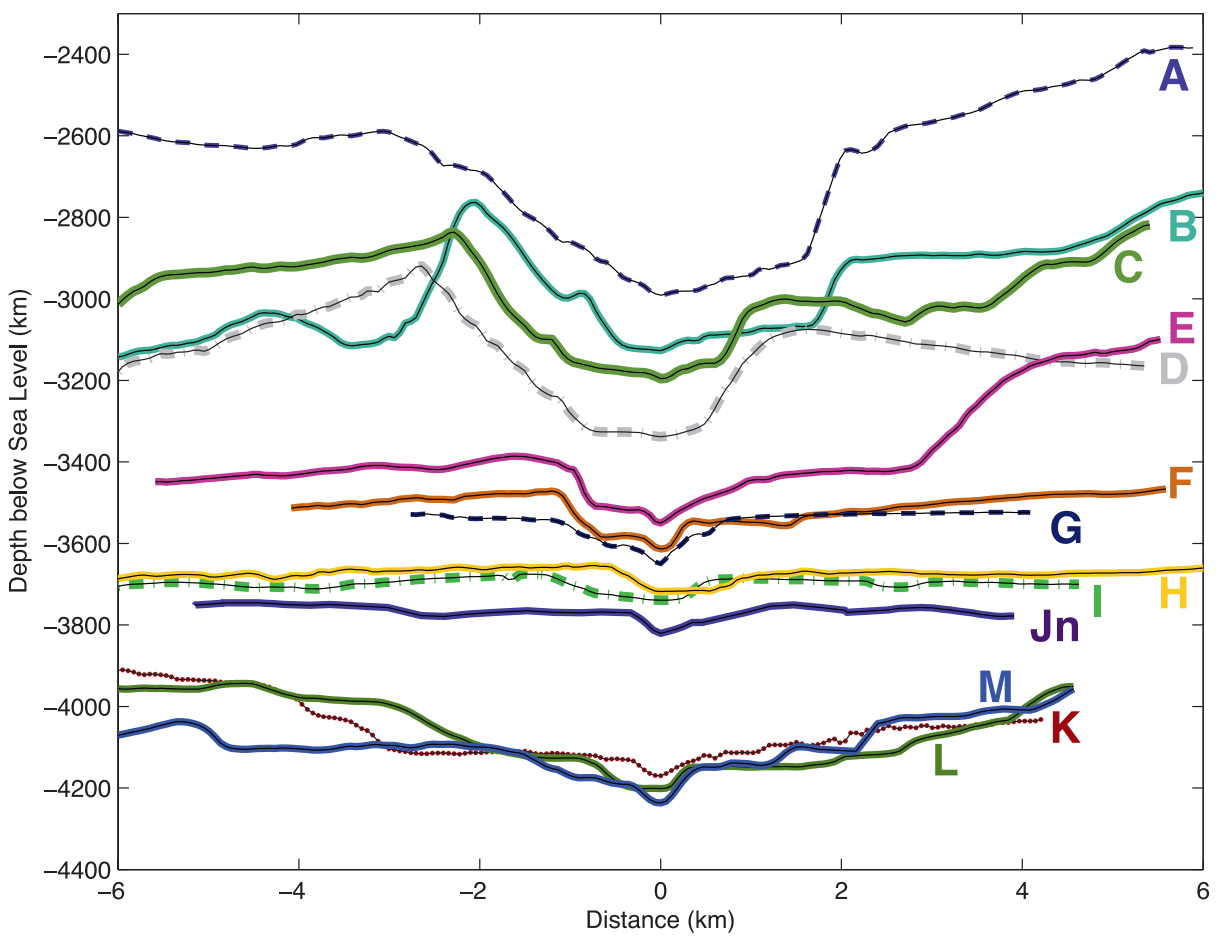

FIG. 4.-Downslope series of canyon profiles, channel, and banks (see Fig. 2 for locations). All are west (left) to east (right) orientations, except for "Jn," which is north to south. Distance on the horizontal scale is east (positive) or west (negative) from the channel minimum depth.

\section{METHODS}

Four sources of bathymetric data were used to analyze the submarine geomorphology of the Arguello submarine canyon/ channel/fan system, from which direct and inferred information was obtained. The bathymetric features were interpreted for canyon/

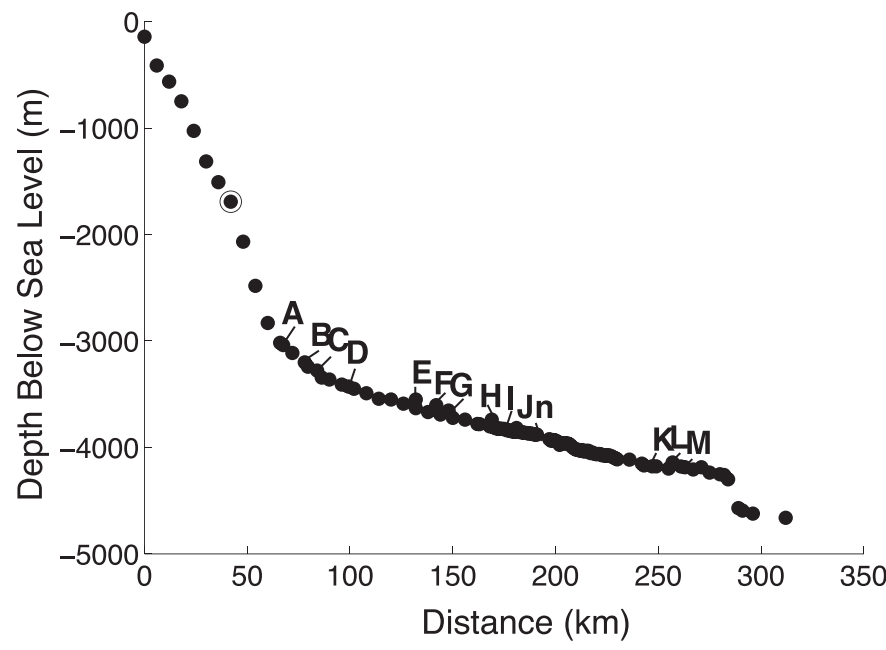

FIG. 3.-Longitudinal thalweg profile for the Arguello Canyon system. Note that these data are taken at regular distance intervals to illustrate total length of channel system rather than straight-line distance. Locations of cross sections A through $\mathrm{M}$ are as indicated in Figure 2. channel depth, length, cross-sectional width, gradient, qualitative sediment accumulation, and transport directions.

The first data set consists of a compilation of high-resolution bathymetric data amassed by the National Centers for Environmental Information, formerly the National Geophysical Data Center (NGDC). Satellite-derived bathymetry data from Smith and Sandwell (1997) were used to fill gaps between the ship tracks of the NGDC data. The most recent bathymetric data were collected during the ALBACORE research cruise in 2010 (Legg et al. 2015). This compilation of over 126 ship track data sets allowed us to create two-dimensional (2D) and three-dimensional (3D) bathymetric maps using the Generic Mapping Tools (GMT; Wessel and Smith 1991) and MB Systems $\subset$ processing software. Selected channel sections of interest were enlarged to allow for accurate analysis of submarine features. First, an overview 2D map of the entire 300+-km-long canyon system was constructed (Fig. 1) with $100-\mathrm{m}$ grid spacing. Ship track data, which provide the highest resolution and covers the entirety of the Arguello channel from source to sink as well as routes to and from the channel, were utilized. The lower resolution Smith and Sandwell (1997) satellite data fill in between ship tracks, but these regions are tangential to our study area and are not the primary area of focus for which measurements were made in this study. This indicates that the smallest channel features at $400 \mathrm{~m}$ or greater are well resolved. Short 3D segment views of the channel system were created at smaller scales to identify viewing or artificial sun-illumination angles that would highlight and focus on important smaller scale features (Fig. 2).

The second data set consists of the MBARI Simrad ${ }^{\circledR}$ EM 300 (MBES) bathymetric data acquired in the head and midslope parts of the Arguello Canyon system. The gullies forming the head of the canyon system were mapped in detail with this swath bathymetric and backscatter system with the data collected in 1998 on board the $R / V$ Ocean Alert by C\&C Technologies of Lafayette, Louisiana, for MBARI. 


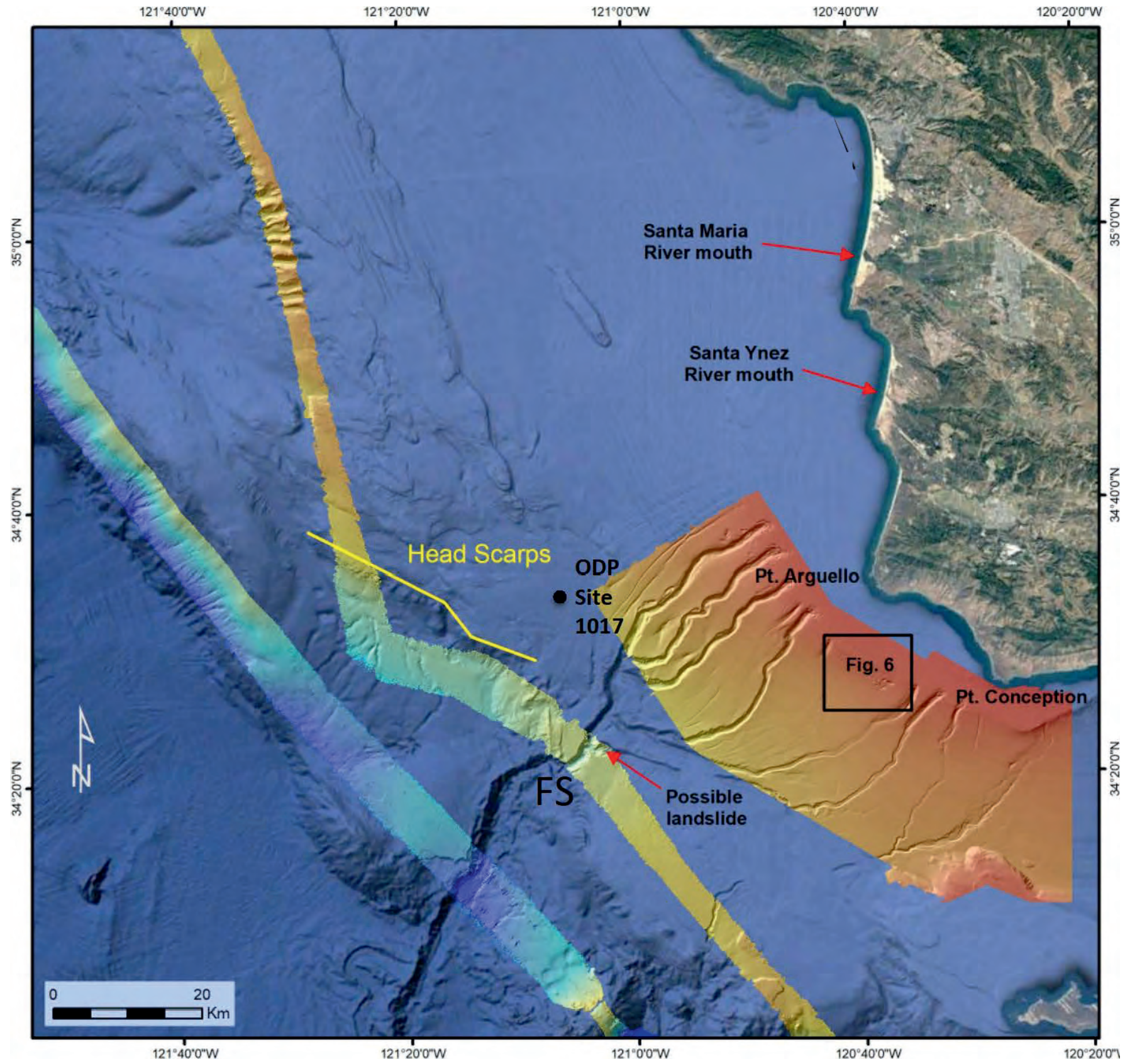

FIG. 5.-Bathymetric images of the head and midslope parts of the Arguello Canyon system. The gullies forming the head of the canyon system were mapped using Simrad EM300 high-resolution MBES swath bathymetric and backscatter data collected in 1998 onboard the R/VOcean Alert by C\&C Technologies of Lafayette, Louisiana, for MBARI (imagery is courtesy of MBARI). The midslope part of the main channel of the canyon was imaged using a hull-mounted Kongsberg EM710 system collected in 2017 aboard the University of Alaska, Fairbank's $R / V$ Sikuliaq. Filled black circle indicates the location of Ocean Drilling Program (ODP) Site 1017 (Lyle et al. 1997). "FS" marks where two NS-oriented faults are imaged and the canyon takes a jog to the north.

The third data set consists of a single MBES line collected in May 2016 across the midslope part of the main channel of the canyon, imaged using a hull-mounted Kongsberg EM710 ${ }^{\mathrm{TM}}$ system aboard the University of Alaska, Fairbank's R/V Sikuliaq.

The fourth data source comprised additional map views of areas poorly covered by the ALBACORE, MBARI, and $R / V$ Sikuliaq data sets generated with Google Earth Pro $\subset$, which is an amalgamation of data extracted from sources listed in the figure captions. Maps showing seismicity were obtained from the National Earthquake Information Center for the time periods indicated and plotted on the figures (maps) shown herein.

Twelve E-W-oriented cross sections (A-I, K-M) and one N-Soriented cross section were constructed using both the NGDC ship track and Google Earth bathymetric data sets to illustrate canyon/ 
channel morphology in selected areas (Fig. 2). Thalweg (channel maximum) depths (Fig. 3) at each cross section (Fig. 4) and elsewhere along the length of the canyon/channel system were measured using both data sets, and a thalweg profile plot was constructed (Fig. 3).

\section{RESULTS}

\section{Arguello Canyon System}

Our bathymetric mapping results show a deeply incised submarine canyon system consisting of multiple heads, a distinct canyon, sea valley, and channel. The system extends from the continental shelf west across the continental slope and the oceanic seafloor and ultimately terminates in a deep bathymetric low and fan (Fig. 2). Features of the system were identified using the along-axis bathymetric profile (Fig. 3), as well as cross-sectional views (Fig. 4) detailed with 7- to $12-\mathrm{km}$ transects centered on the thalweg (deepest canyon/channel depths).

Detailed data from the shelf-to-slope transition (Fig. 5) also show how the canyon profile (depth, width) changes along the length of the system. The heads of the canyon tributaries are located near the shelf edge in water that is only a few hundred meters deep, and the canyon system can be traced downslope to a maximum water depth of $\sim 4500$ $\mathrm{m}$. Numerous tributary channels (canyon heads) originate near the narrow shelf edge (Point Arguello and Point Conception) and extend downslope to the SW and then veer west on the slope to coalesce as hanging valleys with the main Arguello Canyon (Fig. 5). Each successively increases in depth from SE to NW along the slope. Along the length of the system there is evidence of variable levels of erosion, mass wasting, and deposition observed in narrow V-shaped to broad U-shaped canyon profiles, meanders and terraces, arcuate scarps and associated slumped masses, and finally to a channel and depositional low.

The map view, thalweg profiles, and cross sections (Figs. 2-4) illustrate how the Arguello Canyon system can be divided into several segments for the purposes of description and interpretation: Canyon Heads; Upper to Lower Slope Canyon; Base of Slope ("Fan" of von Huene [1969]); Distal Fan and Channel Bend; and Ocean Floor to Depocenter.

Arguello Canyon Heads (CH, Fig. 2): Eight gullies notch the continental shelf break and incise the upper continental slope of the Point Conception-Arguello continental margin. Six of these gullies trend southwest and then abruptly veer WNW to connect with the main Arguello Canyon channel (Fig. 5). The two other gullies initially trend south and feed sediment to the deep seafloor through a slope canyon just north of San Miguel Island in the southern San Miguel gap area. On the shelf, extensive carbonate mounds and slabs are present, while on the slope, pockmarks (circular depressions), coalescing pockmarks (elongated depressions), gullies, and landslides are visible (Fig. 6). The upper tributary gullies of the Arguello Canyon system exhibit collapsed heads and downslope transport of slide blocks. Between the gullies that form the heads of the Arguello Canyon system the slope geomorphology is characteristic of continental slopes influenced by underlying leaking hydrocarbon basins (e.g., Eichhubl et al. 2002, Greene et al. 2002, Saenz 2002). Distinct modern sidewall slumps and other submarine slides are present in the gullies.

Upper to Lower Slope (SL, Fig. 2): The MBES data image the midslope part of Arguello Canyon just at and below the intersection of the sixth or most easterly canyon head gully (Fig. 5). In this region, the geomorphology of the canyon appears youthful and asymmetrical in cross section, with narrow, flat floors and sharp-edged upper walls.
At the intersection of the main Arguello Canyon and the most easterly head gully, the distal end of the gully appears to be hanging. Adjacent to the intersecting gully, the fall to the Arguello channel and bowl-shaped feature may represent a small landslide. A flat, terracelike feature is present on either side of the canyon, with two N-Soriented fault-like scarps, east-facing or west side up, prominently displayed in the bathymetric image that crosses the western part of the terrace (FS in Fig. 5). In this same area, where the canyon extends south to the Arguello upper slope, it exhibits a slight jog to the north at a depth of $\sim 1500 \mathrm{~m}$, then continues on a more west-southwest trend (Figs. 2, 5). Downslope it continues in a fairly straight course to the "fan" or sedimentary apron at the base of slope, which we here label the "slope fan." Several areas of the slope exhibit steep inclines with morphology suggestive of mass wasting, as discussed below.

Base of Slope and Slope Fan (SF, Fig. 2): At the base of the slope, the canyon cuts through a region of irregular topography described by previous workers as a submarine fan (e.g., Von Huene 1969). Only the upper part of the fan is imaged in the ALBACORE data (Figs. 2, 7), but the more complete image provided by the Google Earth data set (Fig. 8) shows fan-like topography extending toward the Rodriguez Seamount to the east.

Our bathymetric mapping results show an older, abandoned channel system in the upper part of the fan that roughly parallels the modern canyon. The relief on this older channel is less pronounced, and the channel floor appears to be relatively flat in area. The width of the channel is relatively uniform but has an irregular, meandering course. The head of the older channel appears to be crosscut by the modern channel (Figs. 7A, 8B) upstream of the location at which the younger channel veers to the south. Unfortunately, the channel passes through an area for which there is incomplete ALBACORE data coverage. Data sets integrated into Google Earth more clearly define this part of the system, however (Fig. 8). These data show the older channel to be shallower than the modern canyon. The edges of the older channel appear corrugated, and the channel becomes progressively narrower to the south, where it abuts a series of volcanic cones. In this area the channel morphology becomes less distinct. The trend of the older channel, $10 \mathrm{~km}$ west of the younger channel, roughly parallels the modern channel for $\sim 50 \mathrm{~km}$. The modern channel cuts into the fan, revealing structure in the canyon walls, as shown in Figure $8 \mathrm{~B}$ and $\mathrm{C}$ (white arrows). Topographic features on the channel floor may be either erosional (cut into more resistant lithologies) or depositional (sediment waves) in origin. Cuspate features along the canyon margin (Fig. 8B, "s" symbol) are locally associated with channel fill (slumps).

The modern Arguello Canyon walls in this area are straight to irregular. There is a significant gap in ALBACORE data between points D and E, as shown in Figure 2. The Google Earth data bridge this gap (Fig. 8A) and show that the hummocky, wave-like ridge morphology of the slope fan continues, with an eastward shift and narrowing of the canyon. South of the gap, the canyon trends almost due south, taking a slightly sinuous and irregular path and exhibiting irregular morphology (Fig. 8).

Distal Fan and Channel Bend (DF, Fig. 2): At approximate latitude $33^{\circ} 18^{\prime} \mathrm{N}$, the modern channel exhibits an abrupt bend to the west (Figs. 2, 8,9), where it may be influenced by topography along the fault-bounded wall of the AFZ. West of the bend, the channel evolves into a wide sinuous system as it traverses $\sim 15 \mathrm{~km}$ across oceanic crust with $\mathrm{N}-\mathrm{S}$-aligned abyssal hill fabric (Fig. 9). In this highly sinuous area, there are features that resemble point-bar and lateral-accretion deposits, as well as transverse step-downs, and potential transverse and longitudinal bedforms (Fig. 8C).

The termination point of the distal fan is uncertain. The canyon profiles (Fig. 4) suggest that the channel has cut down through 

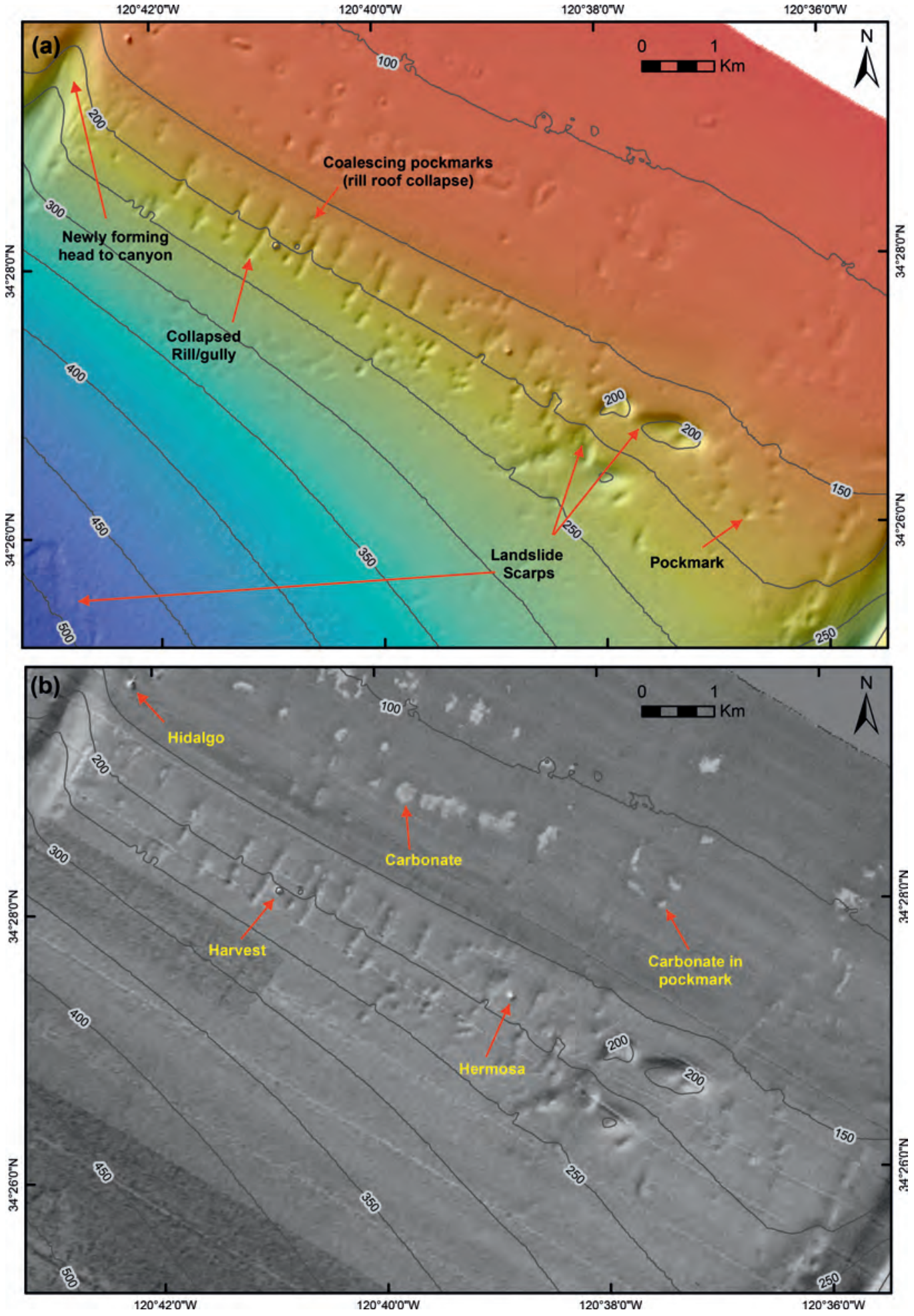

FIG. 6.-Geomorphology of the Arguello-Conception shelf and upper slope showing the various fluid flow features related to the canyon head's development in the Arguello Canyon system: A) Color bathymetry showing fluid flow morphologies and B) backscatter mosaic showing carbonates and substrate types associated with the fluid flow features (imagery courtesy of MBARI). Hidalgo, Harvest, and Hermosa oil platforms show up as white mounds. 

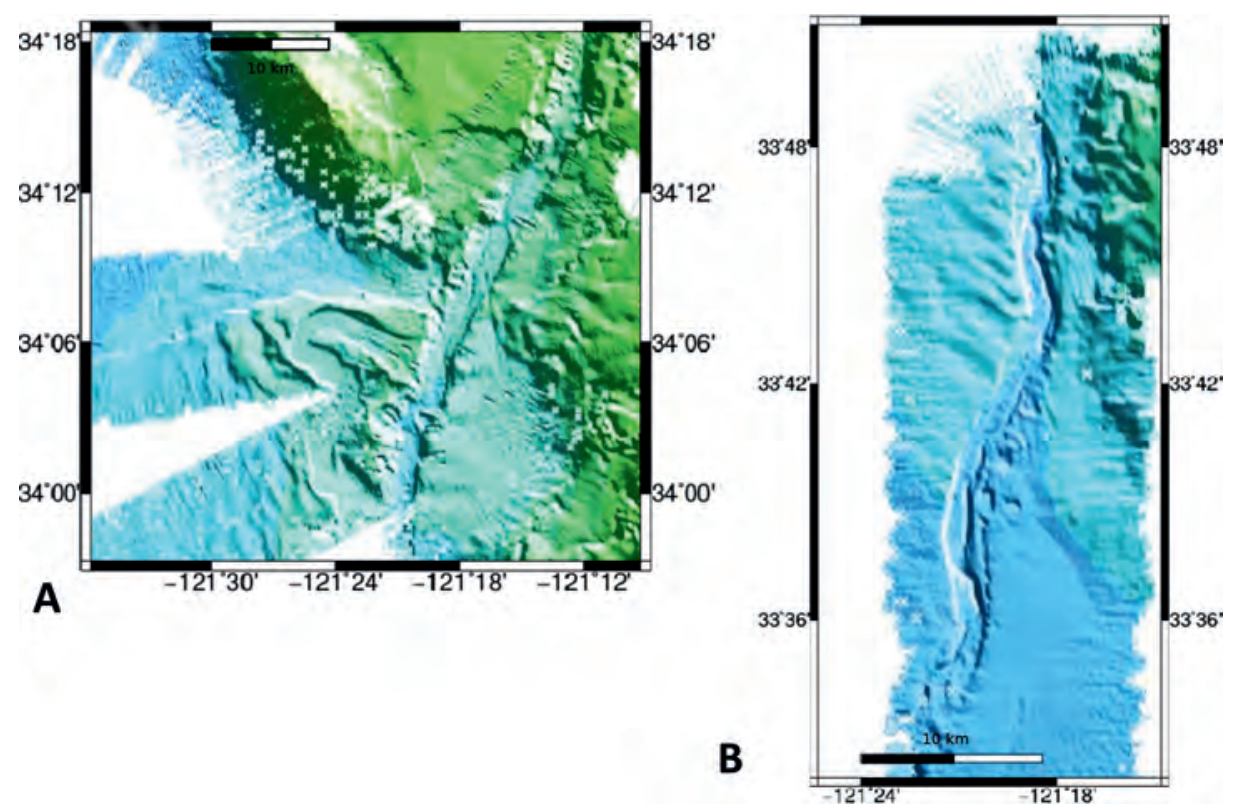

FIG. 7.- - Larger scale segments of Arguello Canyon system outlined as Boxes 1 (A) and 2 (B) in Figure 2: A) highlights the "slope fan" area at the base of the slope and several older channel cut-offs (oxbows), indicating high-volume sediment transport, whereas B) shows the long N$\mathrm{S}$ channel segment.

sediment (fan deposits?) as far south as section H or I. The complex channel morphology pictured in Figure $7 \mathrm{~B}$ is consistent with downcutting through layered deposits. It may continue as far as the meandering segment of the channel. This downcutting pattern is also expressed in the older channel to the west (Fig. 8).

Ocean Floor to Depocenter (OF to DC, Fig. 2): Westward of the meandering segment, the channel straightens (Figs. 2, 8). The channel in this region is relatively narrow $(<1 \mathrm{~km})$ compared to other parts of the Arguello Canyon system (see Figs. 2, 8, 9). The channel veers north and west, skirting around a volcanic edifice that rises $240 \mathrm{~m}$ above the surrounding seafloor (which averages $4100 \mathrm{~m}$ below sea level). The fabrics of the basement on either side of the channel are different, displaying SW-NE-oriented lineations on the volcanic edifice located on the southwest side of the channel and $\mathrm{N}-$ S-lineated abyssal hills on the northeast side of the channel, suggesting that the channel may follow a structural discontinuity in the oceanic basement. The N-S lineations may be a deformed abyssal hill fabric, which displays slight curvature, partly manifested in the terraced northeastern flank of the channel. The canyon then trends due west before emptying into a deep enclosed chasm, which reaches a depth of $4680 \mathrm{~m}$ below sea level (dark blue bathymetry in Fig. 10). The chasm displays steep (cliff) margins on the eastern, western, and southern flanks, and no visible outlet (Fig. 10). The steep drop behind the edifice resembles a terraced cliff facing west with $800 \mathrm{~m}$ total relief. The chasm is elongated, spanning approximately $20 \mathrm{~km} \mathrm{~N}-\mathrm{S}$ and approximately $10 \mathrm{~km} \mathrm{E}-\mathrm{W}$. There is a shallow volcanic ridge west of the chasm and at its southern terminus damming sediments from the east, west, and south. The smooth flat bottom of the depocenter (Fig. 10) starkly contrasts with surrounding basement highs and suggests significant basin infilling, which may mask and underestimate the true depth of the chasm. The volcanic edifice and adjacent deep chasm occur at an offset of two segments of the AFZ (see magnetic seafloor anomalies in Fig. 1). The bathymetry immediately surrounding the chasm is significantly shallower than the surrounding abyssal planes, with irregular arcuate striations that are neither parallel nor perpendicular to the magnetic anomalies. This indicates atypical volcanic flows, which may have experienced intense deformation. A similar deep chasm may also occur along several offsets in the Patton fracture zone (near $32^{\circ} \mathrm{S}$ $\left.121^{\circ}-122^{\circ} \mathrm{W}\right)$.

\section{Conception Canyon}

An unnamed companion canyon, here named "Conception Canyon," is located east of Arguello Canyon and skirts the SE base of Rodriquez Seamount, while Arguello Canyon skirts the NW base of the seamount (Fig. 8A). Conception Canyon trends as a gully south of Point Conception at the western sill to the Santa Barbara Basin and extends in a southerly arc-like fashion toward the SW. The seafloor

FIG. 8.-Bathymetric images created with Google Earth Pro from data provided by SIO, NOAA, US Navy, NGA, GEBCO, Image Landsat, LDE-Columbia, NSF, and MBARI: A) Broader view of entire Arguello Canyon system; B) Enlarged view of the box in A showing the nature of the slope and "slope fan" area; C) enlarged view of "slope fan" (see box in B), with corrugated appearance crosscut by the modern channel. 

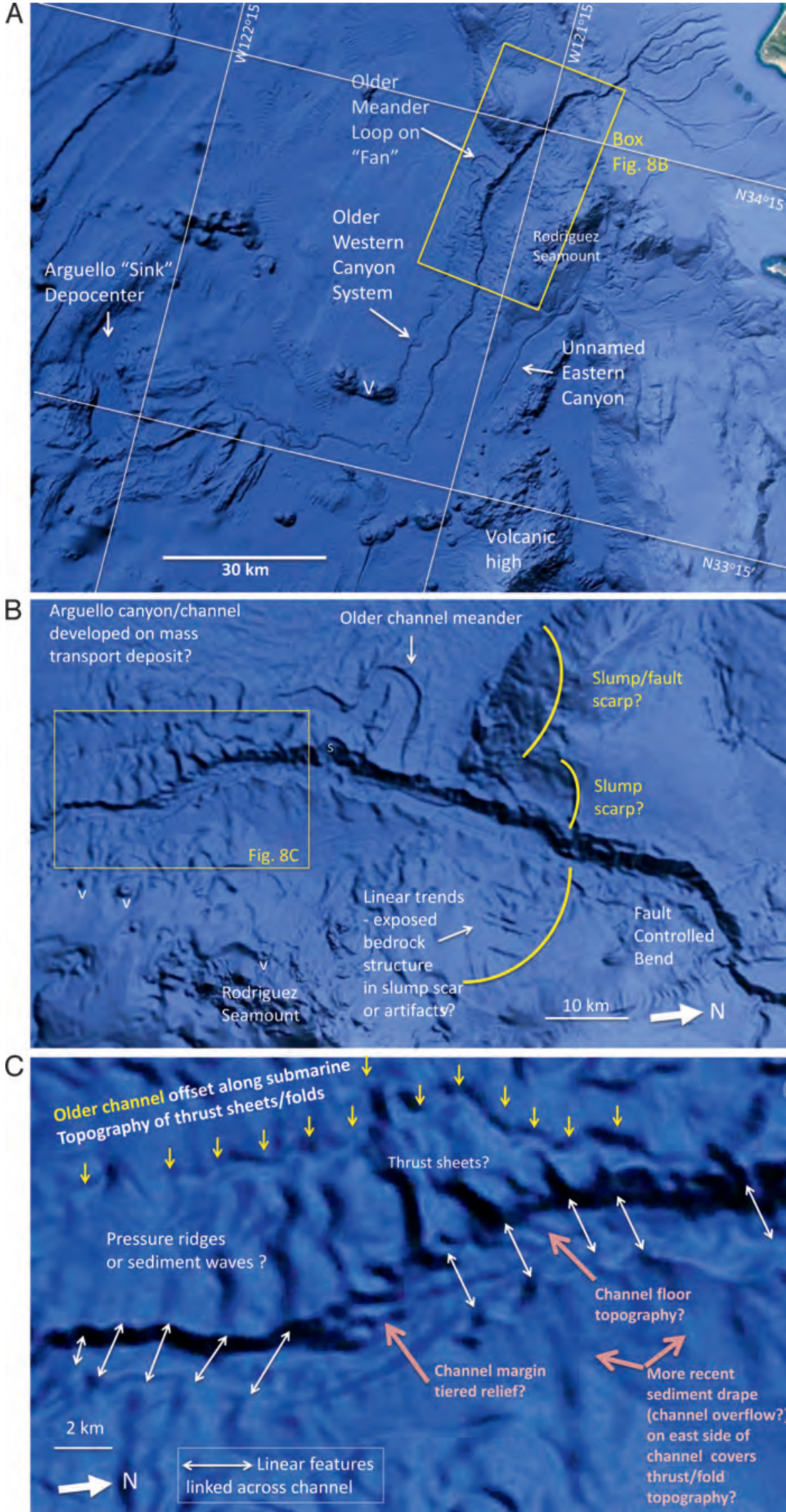

This is an author e-print and is distributed freely by the authors of this article. Not for resale. 


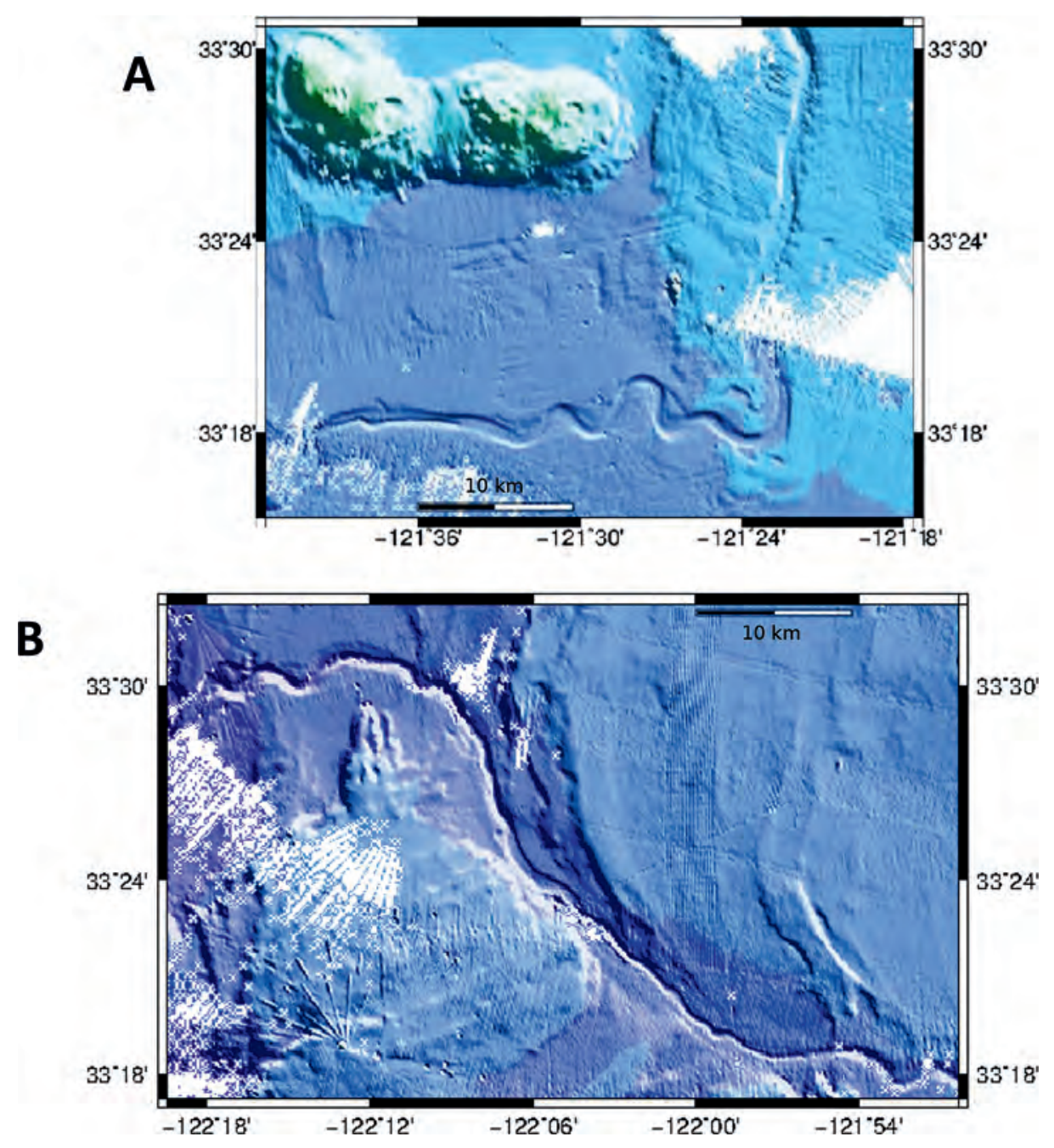

FIg. 9.- Larger scale segment of Arguello system outlined in Boxes 3 (A) and 4 (B) in Figure 2: A) Emphasizes the lower segment of the long segment (Fig. 7B) and the abrupt $90^{\circ}$ bend to the west, whereas B) highlights the east-west transect of the canyon/channel system and northward traverse around the thickened crustal bulge. Abyssal hills oriented N-S are observed north of the channel, which bend slightly where the Arguello channel crosscuts the hills. The depositional chasm in the upper left corner of the map shows the terminus of the Arguello channel and surrounding elevated crustal rock (?) exposures.

expression of the canyon is missing in the available data set (Fig. 8A) for about $15 \mathrm{~km}$ (owing to interpolation across a data gap) and reappears as a fairly linear, narrow, south-trending gully near the center of the terrace, in a similar fashion as described by Maier et al. (2012) for channels offshore of Partington Canyon, south of Point Sur, and as a small incising (?) canyon within the steeply dipping bedrock (?) of the lower slope. The canyon dies out south of Rodriquez Seamount, where it funnels sediment onto the fan-MTS deposits that Arguello Canyon cuts through NW of the Conception Canyon terminus.

\section{DISCUSSION}

\section{General Observations on the Arguello Canyon System}

Various architectural elements defined for other submarine canyon systems (e.g., Heiniö and Davies 2007; Nakajima et al. 2009;
McHargue et al. 2011; Brothers et al. 2013; Maier et al. 2012, 2013) are present in the Arguello Canyon System, such as channels with straight to meandering thalwegs; levees (potential inner levees or arcuate terraces formed by point-bar-like deposition, and outer levees formed by channel overspill of fine turbidites into surrounding hemipelagic zones); outer-bank bars or outer-bend sediment accumulations; arcuate terraces; and knickpoints defined by Heiniö and Davies (2007) as "a reach with higher gradient than the adjacent reaches." In the headward part of Arguello Canyon, tributary hanging valleys are observed, with definite breaks in gradient downslope (Fig. $3)$. These features are characteristic of slopes formed by avulsion, normal faulting, landslide headwalls, or variability in substrate (hard basement rocks vs. soft sedimentary cover), according to Heiniö and Davies (2007) and Jobe et al. (2011), and are described in detail below. More detailed seismic and higher definition bathymetry are needed to further define these features where data gaps are still significant (Fig. 2). 
A

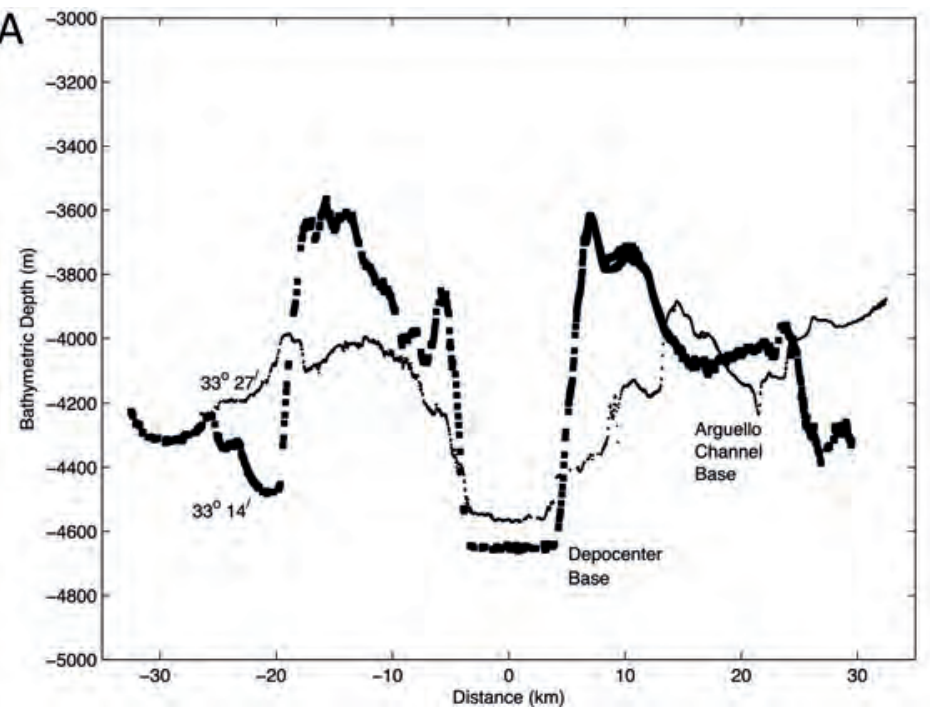

B

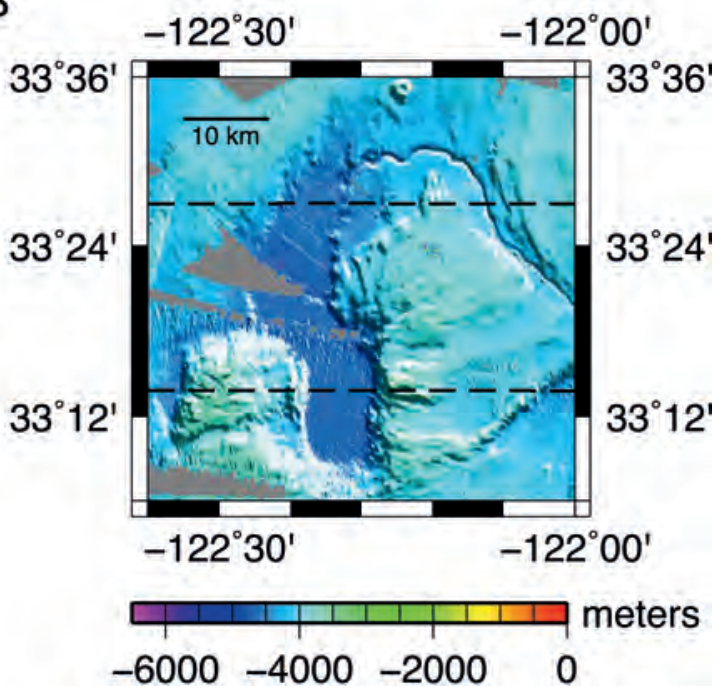

FIG. 10.- Two east-west-oriented bathymetric profiles across the depocenter chasm: A) along the lines of latitude indicated and B) corresponding map illustrating flat bottom (darker blue) of the depositional sink (chasm) that contrasts with the surrounding topography. Note the very steep walls of the southern limb of the chasm.

\section{Arguello Canyon System Head}

The continental shelf and slope in which the six head gullies of the Arguello submarine canyon are located exhibit distinct features attributable to fluid flow out from the seafloor (Fig. 6). For example, observed rill features are similar to those described by Pratson et al. (1994) for the Eastern US coast slope and are composed of depressions similar to features described on land and related to piping (Jones 1990). "Rills," as defined by Pratson et al. (1994), are narrow (20-30-m-wide), shallow (20-40-m-deep), gully-like features that form on the intercanyon divides of the upper continental slope off New Jersey that merge with troughs and result from top-down sediment flow erosion, in contrast to bottom-up erosion through retrogressive slumping. Under subaerial conditions, the formation of rills is due to topographic runoff pirated through a slope failure, with some rills forming at the expense of others to form master channels (Horton 1945). These can eventually lead to canyon development. Piping is the process of forming rills from subsurface fluid flow in sedimentary deposits from which granular material is removed, forming linear depressions that can be identified as rills and aligned pits on the ground surface (Jones 1990). Piping is thought to be the mechanism for the rilling on the Ascension slope (Greene et al. 2002) and appears to be the process forming the head tributary gullies for Arguello Canyon. The head collapses in the upper tributary gullies of Arguello Canyon are similar to those described for Ascension and Ańo Nuevo canyons offshore of central California, where rilling and piping is thought to be the process that formed the canyons (Greene et al. 2002).

The slope areas of the Arguello-Conception canyons, Santa Barbara Channel, and Ascension-Ańo Nuevo canyons are all underlain by petroleum-bearing strata marked by the Point Arguello and Point Pedernales fields of the offshore Santa Maria basin in the Arguello Canyon area and the Outer Santa Cruz Basin in central California. The Arguello Canyon gullies occur in an area in which active extraction of oil and gas is occurring through three petroleum drill platforms (Hidalgo, Harvest, Hermosa) that are located on the upper continental slope (Saenz 2002). We hypothesize that the modern multihead Arguello Canyon system originated through piping driven by fluid or gas leakage from the underlying hydrocarbon basin or through a form of underwater spring sapping. It produced regularly spaced rills and headless canyons, such as those described by Orange et al. (1994), that eventually increased in size and captured one or another to form the six head gullies. This process appears to be continuing today, as suggested by the geomorphologic, youthfullooking collapse heads of the gullies that most likely resulted from fluid flow piping and subsurface excavation of materials at depth. This process undermines the overlying sediment, which retrogressively advances upslope, along with the outward and direct downslope transport of the fluid-entrained sediment flow (density current) and displaced slump material (Fig. 6). This is similar to what has been described in the Santa Barbara Channel by Eichhubl et al. (2002) and Greene et al. (2006), in which many slides nucleated in midslope and subsequently retrogressed upslope, consistent with compaction/fluid expulsion models (Dugan and Flemings 2000). One such slide is visible just west of the fifth gully (counting from the west) and in another that appears to be an incipient gully just east of the fourth gully in the bathymetric image (Fig. 5).

Another process that played a role in the formation of the head gullies is the sediment input from the Santa Maria and Santa Ynez rivers and San Luis Obispo Creek. Through time these rivers have migrated and meandered across the continental shelf (a coastal plain during times of sea-level low stands), reaching the distal edge of the shelf in the Point Arguello-Point Conception area during these periods. Across-shelf and downslope transport of sediment are evidenced by the thin, sandy, turbidite beds found in the Quaternary $(<1.4 \mathrm{Ma})$ section at Ocean Drilling Program Site 1017 (Fig. 5; Lyle et al. 1997). Good documentation of bedrock incision by San Luis Obispo Creek and subsequent repeat erosion of channels within San Luis Obispo Bay indicates that it formed as early as MIS $12(\sim 330$ $350 \mathrm{ka})$ or earlier and as late as MIS $2(\sim 20 \mathrm{ka})$. The later dates were provided using recently collected $3 \mathrm{D}$ seismic-reflection profile data for the evaluation of the seismic hazards probability at the Diablo Canyon Power Plant (PG\&E 2012, Nishenko et al. in 2018). 
These buried channels indicate that there is a fairly long history of river migration across the San Luis Obispo Bay shelf. Sediment supplied by the Santa Ynez River, Santa Maria River, and San Luis Obispo Creek would likely have been captured by the head gullies of the Arguello Canyon system. Although likely not the process of original formation of the heads, as indicated by the regular spacing of the channels, the migration of the rivers along the ArguelloConception shelf almost certainly deepened and widened the gullies.

The bathymetric data indicate that the most westerly canyon head is the most recent active canyon, based on its youthful-looking geomorphology and the manner in which it cuts deeply beneath the other channels to form hanging valleys. The main, westernmost gully also displays distinct sidewall slumps along its western edge that may be the result of active down-gully sediment erosion and undercutting. The other two eastern channels to the east of the main channel also display wall slumps near meanders, but these are not as pronounced as in the main channel and therefore suggest little or no active sediment transport down these gullies today. Furthermore, the Arguello Canyon system extends across the boundary between the sediment-covered shelf north of Point Arguello and the sediment-starved shelf south of Point Arguello (Slater et al. 2002), suggesting that the westernmost gully captures most of the south-flowing sediment from the coastal rivers during sea-level highstands.

The canyon head system also must have funneled much of the sediment transported across the shelf during the last lowstand, as well as that displaced by subsurface fluid flow to the main channel of Arguello Canyon. When the shelf narrows during sea-level lowstands, the canyon is the locus of more direct mass transfer of sediment from littoral drift and multiple river inputs to the slope (Slater et al. 2002). In support of this, Behl et al. (2000) found cyclic Milankovich-scale pulses of coarser silt deposited during lowstands at ODP Site 1017, located on the upper continental slope north of Arguello Canyon, that were interpreted as turbid overbank clouds from the Arguello Canyon system or as possibly related to changes in current strength. This combination of highstand and lowstand sediment transfer in canyon systems has been demonstrated elsewhere in the Inner California Continental Borderland (e.g., Covault and Fildani 2014).

\section{Midslope Arguello Canyon}

The youthful appearance of the midslope reach of the canyon (although flat-floored, which may reflect transient sediment accumulation) suggests that long-term net erosion may occur within this segment of the Arguello Canyon system. Although not shown in the recently collected MBES data, the downslope continuation of the Arguello Canyon appears (in the Google Earth bathymetry) to drop over a slump scarp into a concave-east-facing meander and may be cutting through landslide material (Fig. 5). At the intersection of the main Arguello Canyon and the most easterly head gully, the newly collected MBES bathymetric imagery (i.e., R/V Sikuliaq data) show the proximal end of the gully to be hanging. Above the fall to the Arguello channel, a bowl-shaped feature may represent a small landslide.

To the west of the canyon, the new $R / V$ Sikuliaq bathymetric imagery indicates that the upper slope at the southern end of the Santa Lucia Bank and the western part of the Arguello-Conception slope have been subject to past mass-wasting events, as extensive landslide scarps are present (Fig. 5). To the east of the canyon, the Google Earth bathymetry also indicates past landslide events, suggesting that the mid-Arguello Canyon has been altered by mass wasting through time and that the geometry displayed today represents its postlandslide erosional state.

\section{Arguello Slope Fan vs. Mass Transport Deposits}

According to simplistic actualistic models, one would expect to see a canyon in a proximal location on a submarine fan to radiate into a series of distributary channels that feed depositional lobes downslope of the canyon mouth (e.g., Normark 1970a, Normark et al. 2009). Such a pattern is not apparent on the mound of material (presumed sediment) that has been called the Arguello Fan (see outline on Figs. 1,2), herein termed "Arguello slope fan," so named because of the uncertainty of origin. Overall, the slope fan surface is irregular, with what appears to be a topographically abrupt northern boundary (Figs. $2,8)$. The irregular topography and sinuous channels close to the base of the slope were recognized by previous workers (e.g., von Huene 1969) as anomalous, with the Arguello slope fan showing a larger area, with high slopes and moderate sinuosity, compared with other well-defined fan systems (e.g., Amazon, Monterey). The Arguello slope fan constitutes an end-member point on a sinuosity vs. valley slope plot (Clark et al. 1992, Peakall et al. 2012) based on interpretation of data reported in EEZ-Scan 84 Scientific Staff (1986).

The dissected and corrugated texture of the Arguello slope fan surface is reminiscent of the compression ridges observed at the downslope limits of sediment movement associated with submarine debris flows and mass transport (e.g., Prior et al. 1984, Lee et al. 2002). It could also be attributed to mega sediment waves resulting from massive sediment transport down the canyon. The surface roughness and ridge patterns can be explained by a mass-wasting origin. Thrust sheet boundaries and pressure ridge topography are apparent in cross-sectional views afforded by the crosscutting modern canyon (Fig. 8). We are not certain whether the entire mound of sediment is a single mass transport deposit (MTD), which would represent a massive failure of the slope somewhere, or a submarine fan covered by multiple MTDs. Elsewhere in outcrop, MTDs have been shown to have topographic expressions, locally buried by sandy turbidites, with an alternating stacking pattern suggesting multiple mass-wasting events (e.g., Armitage et al. 2009). Armitage et al. (2009) showed different scales of surface topography on MTDs in outcrop, with wavelengths ranging from several meters to several hundred meters. The Arguello slope fan surface appears to exhibit an even larger scale of surface topography, with wavelengths on the order of kilometers, which may support generation of the slope fan by a single large event. Alternatively, these wave-like sedimentary features could be the product of internal waves.

The bathymetry of the Arguello slope fan is in part molded by an older canyon/channel system, which is crosscut by the younger modern canyon in the upper reaches of the slope fan but which remains intact and parallel to the modern Canyon system downslope (Figs. 2, 7A, 8). The convolute meandering path taken by the older canyon system likely evolved as drainage developed on an irregular surface (e.g., slump blocks, fault- or fold-related ridges) at base level. The oxbow meander at the proximal part of the slope fan is a shallow, wide channel enclosing a topographic high (e.g., sediment wave crest or slump block). Further downslope, the older channel path appears to have also been constrained by surface sediment wave or ridge topography (Fig. 8). We note that the adjacent area to the east of the modern channel is smoother (Fig. 8C); this could be a function of draping by turbidite overflow affected by southeast-flowing currents or precursor topography, for example, older fan deposits on which the MTDs came to rest.

The Arguello Canyon system appears to exhibit a major period of avulsion and meander loop cut-off (Kane et al. 2008), similar to that which has been described for the Shepard Meander in the Monterey Canyon system (Gutmacher and Normark 1993). In particular, the avulsion that resulted in the abandonment of the older channel and production of the modern channel appears to have occurred near the proximal part of the slope fan. Kolla (2007) indicates that in such a 
proximal position, larger currents associated with turbidity or catastrophic flows would be needed. We speculate that avulsion may have also been linked to downslope changes in base level. We hypothesize that a large landslide deposit dammed the Arquello Canyon and elevated the base, flattening the surface so that the sediment flowing down the canyon spread out across the MTD at a base that facilitated the formation of a meandering channel. Eventually the MTD would have been skirted by sediment transport, abandoning the elevated channel. The likely source for the MTD is the steep Santa Lucia Escarpment to the north of the canyon, where past earthquakes may have dislodged massive amounts of materials that slid to the base of the escarpment, traveled as a debris flow southward to block, and filled the canyon. Ultimately, sediment being carried down the slope part of the canyon broke through the lower head meander leg and reoccupied its former channel, eroding through the MTD; this was controlled to a certain extent by the volcanic ridges and highs associated with the oceanic plate (see Fig. 8).

\section{Distal Fan, Bend, and Sink Segments}

Outboard of the California continental margin, north of latitude $33^{\circ} 18^{\prime} \mathrm{N}$, the bathymetry suggests a $\mathrm{N}-\mathrm{S}$ structural grain of oceanic basement, including the orientation of the nearby Rodriguez Seamount produced by magmatism along a zone of crustal weakness at 9 to $11 \mathrm{Ma}$ (Davis et al. 2010). This N-S grain, a likely product of seafloor spreading based on magnetic anomaly patterns, terminates at the E-W-oriented AFZ (Figs. 1, 2), a bathymetric high associated with later volcanism, as evidenced by small volcanic cones (Fig. 8). Changes in structural grain, indicated by seafloor bathymetry to the west and further south, are likely products of complex triple-junction tectonics associated with the Monterey microplate and Rivera Triple Junction (e.g., Nicholson et al. 1994). This oceanic basement structure appears to control the overall orientation of the downslope Arguello Canyon system (as well as the companion Conception Canyon), which trends $\mathrm{N}-\mathrm{S}$, then $\mathrm{E}-\mathrm{W}$, as it abuts the AFZ. It then follows a more convoluted path to its ultimate depocenter.

The southernmost extent of the Arguello slope fan/MTD deposits is uncertain. As the modern channel continues south (Figs. 2, 8), its path appears to be influenced by underlying sedimentary and basement units; terraced steps are evident within the channel (Fig. 7B), with channel narrowing in deeper segments. There appears to be bathymetric expression of the fan/MTD extending out to just before the "Chanel Bend," as indicated by the faint, ridged surface west of the canyon/channel in Figure 7B and the lighter blue (shallower) region to the east in Figure 9A. Furthermore, it is unclear whether the topography south of the Channel Bend (Fig. 9A) is the southernmost expression of the fan/MTD or a large levee (channel overspill) deposit, similar to what has been described for the Shepard Meander in Monterey Canyon (Normark 1970b, Greene et al. 1989). Normally the Coriolis effect would produce a higher levee on the right side of the canyon/channel when looking down-canyon, but such a sharp bend in the channel would result in a spillover point at which the levee is breached by turbidity current flows, as described in Clark et al. (1996).

The abrupt change in channel orientation at the bend may be related to seafloor topographic expression of the AFZ. Meandering of the channel west of the Channel Bend is likely a function of a shallow seafloor gradient (Clark et al. 1996), in which sediment may have initially ponded and inner bend bar sediment accumulated prior to breaking out of the channel to the west. We posit that as sediment accumulated in bathymetric lows within the channel, it ultimately filled and shifted to flow downslope in a straighter E-W orientation. The channel extends for approximately $15 \mathrm{~km}$ before taking a southerly U-shaped trajectory around a bathymetric ridge (possibly a fault-controlled high) and stepping out onto even-deeper oceanic crust. It is then more directly controlled by the topography of oceanic crust with more complex structural grain. The ultimate sink of the Arguello submarine canyon system is a bathymetric depression (Figs. $2,8,10)$. This 4680 -m-deep chasm abuts a large, broad, volcanic ridge that we observe along its eastern, western, and southern banks, which effectively traps the sediment fed by the Arguello Canyon system, preventing further transport of the materials. Bathymetry at the base of this deep chasm is a flat basement floor, consistent with long-term sediment deposition, which may underestimate the depth of the basaltic basement and sediment basin floor. The flat basement floor into which the canyon empties into the chasm displays no depositional features (e.g., "lobe," as described by Kolla [2007]). The shallow bathymetry surrounding the chasm indicates thickened crust from atypical volcanic flows. The nonuniform flow striations or flow fronts observed in the bathymetry surrounding the chasm may indicate intense deformation or local extension associated with regional tectonic activity such as seafloor plate capture (Atwater and Severinghaus 1988) during historic subduction processes or Transverse Range rotation that may extend to the offshore abyssal area in this region.

\section{SUMMARY AND CONCLUSIONS}

The Arguello submarine canyon system is an unusual geomorphic and long-lived submarine complex that is comprehensively described here for the first time, along with a newly discovered companion canyon, here named "Conception Canyon," located east of Arguello Canyon and skirting the SE base of the Rodriquez Seamount. Sediment transported through the canyon system during the Quaternary, and possibly earlier, was most likely primarily sourced from the Santa Maria River, Santa Ynez River, and San Luis Obispo Creek drainage basins.

For descriptive and interpretive purposes, we divided the canyon system into major components based on physiography, depth, geomorphology, and likely mechanisms of erosion and deposition; canyon head gullies, slope canyon, slope fan, distal fan and channel bend, ocean floor deep-sea channel to sea valley, and a terminus depocenter. The shallow head of the canyon system is characterized by six gullies that notch the distal edge of the shelf and feed the primary canyon to the west (Fig. 5). These gullies exhibit rills, slumps, pockmarks, and carbonate deposits that show evidence of gas and fluid flow/seepage from the Point Arguello hydrocarbon basin at depth and that are eroded retrogressively (Fig. 6). These gullies were most likely modified and acted as conduits for sediment transport sourced from riverine systems that meandered across a wide and expansive coastal plain during lowstands of sea level. At and below the intersections of the head gullies and the slope canyon, the active channel appears as a fairly linear feature that is well incised into the bedrock of the southern Santa Lucia Bank (Fig. 8) and then cuts through landslide deposits at the base of the Santa Lucia Escarpment.

From the base of the Santa Lucia Escarpment, the canyon appears to cut through an older submarine fan and MTDs, as suggested by the seafloor morphology. The likely source for the MTDs is the steep Santa Lucia Escarpment to the north of the canyon, where seismic activity may have destabilized the slope, The existence of an abandoned, older canyon and oxbow meander (Fig. 7A) shallowly incised into the fan-MTD west of the modern canyon suggests that fairly recently a large or multiple mass-wasting event(s) traveled southward to cut off the original canyon at the base of the Santa Lucia Escarpment sometime in the past (age not known). This MTD changed the base level for the canyon at this location, causing the large headward, now cut-off (oxbow) meander, shifting the canyon axis and forming a south-trending, high-frequency meandering channel that weaved its way downslope through the existing topography. 
At what appears to be the distal edge of the Arguello slope fan or MTDs, there is a bend in the Arguello Canyon, expressed as a channel meander. This meander shifts the orientation of the canyon axis $90^{\circ}$, from $\mathrm{N}-\mathrm{S}$ to $\mathrm{E}-\mathrm{W}$, perhaps as a function of topographic barrier associated with the AFZ. A lobe of material south of the meander likely represents spillover channel materials (Fig. 9A). From the channel bend, the westward-trending system continues as a wellincised, meandering, deep-sea channel extending through a flat, broad, sediment-laden plain sandwiched between $\mathrm{N}-\mathrm{S}$-oriented abyssal hill fabric, then transitioning into a well-incised sea valley that likely cuts through the bedrock of the oceanic Pacific plate basaltic crust. The terminus of the Arguello submarine canyon system is located in an elongate bathymetric depression reaching $4680 \mathrm{~m}$ in depth below sea level (800-m relief), with a flat basin floor consistent with long-term sediment deposition.

This study sheds light on how the Arguello Canyon system evolved and its significance as a major sediment conduit to the deep sea; however, much work remains to be done to further document our conclusions and to date the system's activity, including additional MBES bathymetry and backscatter data to fill data gaps; seismicreflection subbottom profiles to determine the sedimentary stratigraphy through which the canyon system cuts and the nature of associated sedimentary deposits; and coring, dredging, or ROV sampling to determine the lithology and to constrain the age of the stratigraphy. The depocenter appears to represent a confined terminus for all sediment transported from source to sink, and basin fill could verify not only the history of canyon evolution but also that of the past (Tertiary) seismicity and tectonic development of the central California margin. Such additional information could answer many questions about the origin and evolution of submarine canyons, an objective that would be applauded by our late good friend and colleague Donn Gorsline.

\section{ACKNOWLEDGMENTS}

This work was supported by a grant to B. Rodriguez from the California State University Council on Ocean Affairs, Science and Technology (COAST) Undergraduate Research Support Program. Bathymetry data collection and processing were supported by National Science Foundation (NSF) OCE 0825254 and \#0824982 research grants to M.D. Kohler (Caltech and the University of California, Los Angeles) and D.S. Weeraratne (California State University, Northridge) utilizing UNOLS research vessel and OBSIP instrumentation facilities at the Scripps Institution of Oceanography and NSF-CAREER EAR and the CSUN GEM program grant 1151941 to D.S. Weeraratne. We wish to thank the University of Alaska-Fairbanks and the NSF for collecting an MBES line across our area of interest using the $R / V$ Sikuliaq and Pacific Gas \& Electric Co. for providing data on channel development in San Luis Obispo Bay. Norman Maher assisted in the construction of figures. Reviewers Katie Maier and Peter Dartnell and editors Rick Behl and Jon Schwalbach provided insightful comments. We thank them all for their assistance.

\section{REFERENCES}

Armitage DA, Romans BW, Covault JA, Graham SA. 2009. The influence of mass-transport-deposit surface topography on the evolution of turbidite architecture: The Sierra Contreras, Tres Pasos Formation (Cretaceous), Southern Chile. Journal of Sedimentary Research 79:287-301.

Atwater T, Severinghaus J. 1988. Tectonic maps of the northeast Pacific. In Winterer EL, Hussong DM, Decker RW (Editors). The Eastern Pacific Ocean and Hawaii: The Geology of North America, Decade of North American Geology Vol. N: Geological Society of America, Boulder, Colorado. p. 21-72.
Behl RJ, Tada R, Irino T. 2000. Late Quaternary textural change offshore of Point Conception, Site 1017, central California margin. In Lyle M, Koizumi I, Richter C, Moore TC Jr (Editors). Proceedings of the Ocean Drilling Program, Scientific Results, Vol. 167: Ocean Drilling Program, Texas A\&M University, College Station, Texas. p. 255-261.

Brothers DS, ten Brink US, Andrews BD, Chaytor JD. 2013. Geomorphic characterization of the U.S. Atlantic continental margin. Marine Geology 337:53-66.

Buffington EC. 1952. Submarine "Natural levees." The Journal of Geology 60:473-479.

Clark JD, Kenyon NH, Pickering KT. 1992. Quantitative analysis of the geometry of submarine channels: Implications for the classification of submarine fans. Geology 20:633-636.

Clark JD, Pickering KT. 1996. Architectural elements and growth patterns of submarine channels: application to hydrocarbon exploration. American Association of Petroleum Geologists Bulletin 80:194-220.

Covault JA, Fildani A. 2014. Continental shelves as sediment capacitors or conveyers: Source-to-sink insights from the tectonically active Oceanside shelf, southern California, USA. In Chiocci FL, Chivas AR (Editors). Continental Shelves of the World: Their Evolution During the Last GlacioEustatic Cycle, Memoir 41: Geological Society, London. p. 315-326.

Davis AS, Clague DA, Paduan JB. 2010. Origin of volcanic seamounts at the continental margin of California related to changes in plate margins. Geochemistry, Geophysics, Geosystems 11, https://doi.org/10.1029/ 2010GC003064.

Dugan B, Flemings PB. 2000. Overpressure and fluid flow in the New Jersey continental slope: Implications for slope failure and cold seeps. Science 289:288-291.

EEZ-Scan 84 Scientific Staff. 1986. Atlas of the U.S. Exclusive Economic Zone Western Conterminous United States: US Geological Survey Miscellaneous Investigation I-1792, scale 1:500,000.

Eichhubl P, Greene HG, Maher N. 2002. Physiography of an active transpressive margin basin: High-resolution bathymetry of the Santa Barbara Basin, southern California Continental Borderland. Marine Geology 181:95120.

Greene HG, Maher NM, Paull CK. 2002. Physiography of the Monterey Bay National Marine Sanctuary and implications about continental margin development. Marine Geology 181:55-82.

Greene HG, Murai LY, Watts P, Maher NA, Fisher MA, Paull CE, Eichhubl P. 2006. Submarine landslides in the Santa Barbara Channel as potential tsunami sources. Natural Hazards and Earth System Sciences 6:63-88.

Greene HG, Stubblefield WL, Theberge HE Jr. 1989. Geology of the Monterey submarine canyon system and adjacent areas, offshore central California: US Geological Survey Open-File Report 33, 89-221, 4 maps.

Gutmacher CE, Normark WR. 1993. Sur submarine landslide, a deep-water sediment slope failure. In Schwab WC, Lee HJ, Twichell DC (Editors). Submarine Landslides; Selected Studies in the US Exclusive Economic Zone, Bulletin 2002: US Geological Survey, Denver, Colorado. p. 158-166.

Heiniö P, Davies RJ. 2007. Knickpoint migration in submarine channels in response to fold growth, western Niger Delta. Marine and Petroleum Geology 24:434-449.

Horton RE. 1945. Erosional development of streams and their drainage basins: Hydrophysical approach to quantitative morphology. Geological Society of America Bulletin 56:275-370.

Jobe ZR, Lowe DR, Uchytil SJ. 2011. Two fundamentally different types of submarine canyons along the continental margin of Equatorial Guinea. Marine and Petroleum Geology 28:843-860.

Jones JAA. 1990. Piping effects in humid lands. In Higgins CG, Coats DR (Editors). Groundwater Geomorphology: The Role of Subsurface Water in Earth-Surface Processes and Landforms, Special Paper 252: Geological Society of America, Boulder, Colorado. p. 111-138.

Kane IA, McCaffrey WD, Peakall J. 2008. Controls on sinuosity evolution within submarine channels. Geology 36:287-290.

Kolla V. 2007. A review of sinuous channel avulsion patterns in some major deep-sea fans and factors controlling them. Marine and Petroleum Geology 24:450-469.

Lee HJ, Syvitski JPM, Parker G, Orange D, Locat J, Hutton EWH, Imran J. 2002. Distinguishing sediment waves from slope failure deposits: field 
examples, including the 'Humboldt slide', and modeling results. Marine Geology 192:79-104.

Legg MR, Kohler MD, Shintaku N, Weeraratne D. 2015. High-resolution mapping of two large-scale transpressive fault zones in the California Continental Borderland: Santa Cruz-Catalina Ridge and Ferrelo faults. Journal of Geophysical Research: Earth Surface 120:915-942.

Luyendyk BP. 1991. A model for Neogene crustal rotations, transtension, and transpression in southern California. Geological Society of American Bulletin 103:1528-1536.

Lyle M, Koizumi I, Richter C, Moore TC Jr (Editors). 1997. Proceedings of the Ocean Drilling Program, Scientific Results, Vol. 167: Ocean Drilling Program, Texas A\&M University, College Station.

Maier KL, Fildani A, McHargue T, Paull CK, Graham SA, Caress DW. 2012. Punctuated deep-water channel migration: High-resolution subsurface data from the Lucia Chica channel system, offshore California, USA. Journal of Sedimentary Research 82:1-8.

Maier KL, Fildani A, Paull CK, McHargue TR, Graham SA, Caress DW. 2013. Deep-sea channel evolution and stratigraphic architecture from inception to abandonment from high-resolution Autonomous Underwater Vehicle surveys offshore central California. Sedimentology 60:935-960.

McHargue T, Pyrcz MJ, Sullivan MD, Clark JD, Fildani A, Romans BW, Covault JA, Levy M, Posamentier HW, Drinkwater NJ. 2011. Architecture of turbidite channel systems on the continental slope: Patterns and predictions. Marine and Petroleum Geology 28:728-743.

Menard HW. 1955. Deep-sea channels, topography, and sedimentation. American Association of Petroleum Geologists Bulletin 39:236-255.

Menard HW. 1960. Possible pre-Pleistocene deep-sea fans off central California. Geological Society of America Bulletin 71:1271-1278.

Nakajima T, Peakall J, McCaffrey WD, Paton DA, Thompson PJP. 2009. Outerbank bars: A new intra-channel architectural element within sinuous submarine slope channels. Journal of Sedimentary Research 79:872-886.

Nicholson C, Sorlien CC, Atwater T, Crowell JC, Luyendyk BP. 1994. Microplate capture, rotation of the western Transverse Ranges, and initiation of the San Andreas transform as a low-angle fault system. Geology 22:491495.

Nishenko S, Greene HG, Hogan P, Bergkamp B. 2018. Paleoseismicity of the Shoreline and Oceano fault zones, San Luis Obispo Bay, California. Seismological Society of America Bulletin. https://doi.org/10.1785/ 0120160177

Normark WR. 1970a. Growth patterns of deep-sea fans. American Association of Petroleum Geologists Bulletin 54:2170-2195.

Normark WR. 1970b. Channel piracy on Monterey deep-sea fan. Deep Sea Research 17:837-846.

Normark WR, Piper DJW, Romans BW, Covault JA, Dartnell P, Sliter RW. 2009. Submarine canyon and fan systems of the California Continental Borderland. In Lee HJ, Normark WR (Editors). Earth Science in the Urban Ocean: The Southern California Continental Borderland, Special Paper 454: Geological Society of America, Boulder, Colorado. p. 141-168.

Orange DL, Anderson RS, Breen NA. 1994. Regular canyon spacing in the submarine environment: The link between hydrology and geomorphology. GSA Today 4:35-39.

Pacific Gas and Electric Company (PG\&E). 2012. DCPP 3D/2D SeismicReflection Investigation of Structures Associated with the Northern Shoreline Seismicity Sublineament of the Point Buchon Region: PG\&E Technical Report GEO.DCPP.TR.12.01, San Francisco.

Palmer HD. 1964. Marine geology of Rodriguez Seamount. Deep-Sea Research 11:737-756.

Peakall J, Kane IA, Masson DG, Keevil G, McCaffrey W, Corney R. 2012. Global (latitudinal) variation in submarine channel sinuosity. Geology 40:11-14.

Pratson LF, Ryan WBF, Mountain GS, Twichell DC. 1994. Submarine canyon initiation by downslope-eroding sediment flow: Evidence in late Cenozoic strata on the New Jersey continental slope. Geological Society of America Bulletin 106:395-412.

Prior DB, Bornhold BD, Johns MW. 1984. Depositional characteristics of a submarine debris flow. Journal of Geology 92:707-727.

Reynolds S, Gorsline DS. 1988. Some enigmatic depressions of the Arguello slope, California. Geo-Marine Letters 8:167-172.
Saenz JM. 2002. Geologic controls of hydrocarbon seeps in Santa Maria Basin, offshore California [MS Thesis]: California State University-Northridge, 292 p.

Shepard FP, Emery KO. 1941. Submarine Topography Off the California Coast, Special Paper 31: Geological Society of America, Boulder, Colorado. $171 \mathrm{p}$.

Slater RA, Gorsline DS, Kolpack RL, Shiller GI. 2002. Post-glacial sediments of the Californian shelf from Cape San Martin to the US-Mexico Border Quaternary International 92:45-61.

Smith WHF, Sandwell DT. 1997. Global seafloor topography from satellite altimetry and ship depth soundings. Science 277:1957-1962.

Von Huene R. 1969. Geologic structure between the Murray fracture zone and the Transverse ranges. Marine Geology 7:475-499.

Wessel P, Smith WHF. 1991. Free software helps map and display data. EOS Transactions 72:441, 445-446. 